ARCHIWUM INŻYNIERII PRODUKCJI

PRODUCTION

ENGINEERING

ARCHIVES
2015,Vol. 7, No 2, pp 45-48

ISSN 2353-5156

ISSN 2353-7779 (print version)

(online version)

Article history: $\quad$ Received: 19.12.2014

Accepted: 27.03.2015

Online: 30.04.2015

Available online on: http://www.qpij.pl

Exist since $4^{\text {th }}$ quarter 2013

\title{
Safety restrictions in the logistics of dangerous and toxic substances
}

\author{
Dorota Klimecka-Tatar ${ }^{1}$ \\ ${ }^{1}$ Institute of Production Engineering, Czestochowa University of Technology, Poland, klimt@wip.pcz.pl
}

\begin{abstract}
In this work the difficulties of a safety restriction in the transport of chemical substances is explored. The ranking of dangerous substances and materials is presented to indicate that substances used in various industries have been called hazardous. Transport of substances classified in hazardous group or even toxic is regulated by international rules, which apply in all countries of Europe - The European Agreement Concerning the International Carriage of Dangerous Goods by Road. This legislation aimed to eliminate or reduce the risks associated with transport of dangerous substances. The main aim of this article is to present the most important aspects which entrepreneurs planning the logistics of hazardous substances should consider.
\end{abstract}

Key words - logistic, safety regulation, hazardous substance

\section{Classification of dangerous substances}

The materials (goods) and objects which carriage (transport) is prohibited under the laws and their transport is allowed only under the conditions specified in the ADR regulations are called dangerous (Bubbico R., Di Cave, S., Mazzarotta, B. 2004, ELSHAFEY M.M. et al. 2009, FÖRSTER H., GÜNTHER W. 2009, Gerbec M. 2008, KunCyté R. ET AL. 2003, LEE. C.C. 1986, OPPELT E.T. 1987).

Transport of dangerous materials is defined by the ADR European contract established in Geneva on 30 September 1957 under the auspices of the United Nations Economic Commission, developed and published by The European Agreement concerning the International Carriage of Dangerous Goods by Road, ratified by Poland in 1975. ADR regulations for the carriage of dangerous substances are updated every two years (the beginning of odd).

\subsection{The ranking of dangerous substances}

All materials or substances having dangerous characterisitcs must be identified, classified and named standard unique names used in the ADR regulations on the carriage of dangerous goods. Dangerous materials are classified in one of 13 classes. Each material has its own position marked four- number (UN) and is assigned to one of three packaging groups (PG). These four pieces of information (UN, name by ADR, class, and PG) are enough to identify any dangerous material. Dangerous materials are classified according to the following priority ranking of risks (Table 1 ). 


\subsection{Material safety data sheets (MSDS) in RECH system}

The fundamental tool used in REACH to ensure the flow of information in the supply chain to initiate measures to guarantee the safety and protection of human health and the environment are the chemical safety data sheets. The Safety Data Sheets must include information about the dangers of substance or preparation, as well as information on the recommended risk management measures necessary to adequately control dangers to health and the environment. In accordance with Article. 31 of the REACH Regulation the supplier of a substance or preparation to the recipient also provides the MSDS in the official language of the country in which the substance or preparation is placed on the market (based on Regulation (EC) No 1907/2006 of the European Parliament and of the Council, Official Journal of the European Union, L 136/3 and UK REACH Competent Authority Information Leaflet Number 8 - Exemptions - January 2009).

On the other hand the priority list of "most toxic" substances, based on a prioritization of substances based on a combination of their frequency, toxicity, and potential for human exposure (Table 2).

Table 1. The risk ranking of dangerous substances (materials)

\begin{tabular}{|c|c|c|}
\hline No. & Class & Characteristic \\
\hline 1. & 1 & Explosive and pyrotechnic materials \\
\hline 2. & 2 & Gases \\
\hline 3. & 3 & Flammable liquids \\
\hline 4. & 4.1 & $\begin{array}{l}\text { Flammable solids materials, self-reactive substances and solid } \\
\text { desensitized explosives }\end{array}$ \\
\hline 5. & 4.2 & Flammable materials \\
\hline 6. & 4.3 & Substances which in contact with water emit flammable gases \\
\hline 7. & 5.1 & Oxidizing substances \\
\hline 8. & 5.2 & $\begin{array}{l}\text { Organic peroxides } \\
\text { P1 - Organic peroxides, without temperature control, P2 - } \\
\text { Organic peroxides, temperature controlled }\end{array}$ \\
\hline 9. & 6.1 & Toxic substances \\
\hline 10. & 6.2 & Infectious substances \\
\hline 11. & 7 & Radioactive materials \\
\hline 12. & 8 & Caustic materials \\
\hline 13. & 9 & $\begin{array}{l}\text { Various dangerous substances and articles } \\
\text { M1 - Materials that if inhaled in the form of fine dust, may } \\
\text { constitute a danger for health } \\
\text { M2 - Materials and instruments, which in case of fire may form } \\
\text { dioxins } \\
\text { M3 - The materials give off flammable vapors } \\
\text { M4 - Lithium accumulators } \\
\text { M5 - Emergency items } \\
\text { M6-M8 - Environmentally hazardous materials } \\
\text { M9-M10 - Materials with high temperature } \\
\text { M11 - Other hazardous materials, do not corresponded to the } \\
\text { definitions of other classes }\end{array}$ \\
\hline
\end{tabular}

Table 2. Top ten of the priority list of hazardous substances

\begin{tabular}{|c|c|c|c|c|c|c|c|c|c|c|c|c|c|c|c|c|c|c|}
\hline $\begin{array}{l}\frac{y}{\frac{1}{0}} \\
\frac{0}{m} \\
\stackrel{N}{0}\end{array}$ & 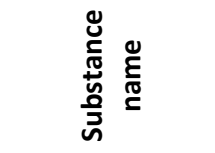 & కn & $\begin{array}{l}\text { 䒘 } \\
\stackrel{0}{0} \\
\stackrel{0}{0}\end{array}$ & 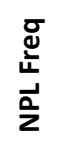 & 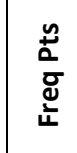 & 음 & 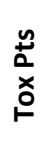 & 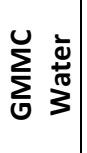 & $\begin{array}{l}\overline{\overline{0}} \\
\text { ú } \\
\sum_{0}\end{array}$ & 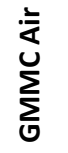 & 음 & ט & $\begin{array}{l}n \\
\tilde{a} \\
\sim\end{array}$ & $\begin{array}{l}u \\
0 \\
+ \\
\frac{0}{x}\end{array}$ & $\begin{array}{l}\sum \\
0 \\
+ \\
0 \\
x\end{array}$ & $\begin{array}{l}\sum \\
0 \\
+0 \\
\frac{0}{x} \\
a\end{array}$ & 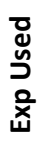 & $\begin{array}{l}n \\
0 \\
0 \\
x \\
x\end{array}$ \\
\hline 1 & arsenic & $007440-38-2$ & 1670 & 1140 & 538 & 1 & 600 & $6 \mathrm{E}-02$ & $5 E+01$ & $8 \mathrm{E}-05$ & $7 E-02$ & $7 E-02$ & 242 & 532 & 719 & 1794 & 1 & 290 \\
\hline 2 & lead & $007439-92-1$ & 1529 & 1272 & 600 & 10 & 400 & $1 \mathrm{E}-01$ & $9 \mathrm{E}+02$ & \begin{tabular}{|l|l|}
$3 E-03$ \\
\end{tabular} & $3 \mathrm{E}-01$ & $3 \mathrm{E}-02$ & 229 & 588 & 843 & 2400 & 1 & 300 \\
\hline 3 & mercury & 007439-97-6 & 1459 & 832 & 392 & 1 & 600 & $3 E-03$ & $3 E+00$ & $3 \mathrm{E}-03$ & $5 \mathrm{E}-02$ & $5 \mathrm{E}-02$ & 237 & 173 & 302 & 640 & 1 & 229 \\
\hline 4 & vinyl chloride & $000075-01-4$ & 1360 & 593 & 280 & 1 & 600 & $6 \mathrm{E}-02$ & $1 \mathrm{E}+00$ & $\begin{array}{ll}9 \mathrm{E}-03 \\
\end{array}$ & $2 \mathrm{E}-01$ & $2 \mathrm{E}-01$ & 259 & 125 & 139 & 410 & 1 & 221 \\
\hline 5 & $\begin{array}{c}\text { polychlorinated } \\
\text { biphenyls }\end{array}$ & $001336-36-3$ & 1344 & 547 & 258 & 1 & 600 & $1 \mathrm{E}-02$ & $9 \mathrm{E}+01$ & $1 \mathrm{E}-03$ & $5 E-02$ & $5 \mathrm{E}-02$ & 237 & 283 & 368 & 884 & 1 & 248 \\
\hline 6 & benzene & $000071-43-2$ & 1328 & 972 & 458 & 10 & 400 & $6 \mathrm{E}-02$ & $1 \mathrm{E}+00$ & $3 \mathrm{E}-02$ & $5 \mathrm{E}-01$ & $5 \mathrm{E}-02$ & 236 & 201 & 302 & 936 & 1 & 234 \\
\hline 7 & cadmium & $007440-43-9$ & 1319 & 1003 & 473 & 10 & 400 & $4 \mathrm{E}-02$ & $2 E+01$ & $1 \mathrm{E}-04$ & $4 \mathrm{E}-02$ & $4 \mathrm{E}-03$ & 196 & 293 & 469 & 1113 & 1 & 250 \\
\hline 8 & benzo(a)pyrene & $000050-32-8$ & 1305 & 545 & 257 & 1 & 600 & $3 \mathrm{E}-02$ & $7 \mathrm{E}+00$ & $3 \mathrm{E}-04$ & $4 \mathrm{E}-02$ & $4 \mathrm{E}-02$ & 231 & 99 & 239 & 534 & 1 & 217 \\
\hline 9 & $\begin{array}{c}\text { polycyclic aromatic } \\
\text { hydrocarbons }\end{array}$ & $130498-29-2$ & 1280 & 401 & 189 & 1 & 600 & $2 \mathrm{E}-01$ & $2 \mathrm{E}+02$ & $1 \mathrm{E}-03$ & $3 \mathrm{E}-01$ & $3 \mathrm{E}-01$ & 266 & 147 & 184 & 630 & 1 & 225 \\
\hline 10 & benzo(b)fluoranthene & $000205-99-2$ & 1251 & 450 & 212 & 1 & 600 & $3 \mathrm{E}-02$ & $1 \mathrm{E}+01$ & $7 \mathrm{7E}-06$ & $4 \mathrm{E}-02$ & $4 \mathrm{E}-02$ & 230 & 52 & 181 & 345 & 1 & 209 \\
\hline $\begin{array}{l}\text { CAS } \\
\text { Total } \\
\text { NPL } \\
\text { Freq } \\
\text { Tox - } \\
\text { it } \\
\text { Tox } P\end{array}$ & $\begin{array}{l}\text { Chemical Abstracts } \\
\text { Jumber; } \\
\text { ts - Total Points; } \\
\text { req - National Prior } \\
\text { ts - Frequency poin } \\
\text { eportable Quantity } \\
\text { Environmental Sco } \\
\text { - Toxicity Points; }\end{array}$ & $\begin{array}{l}\text { List freq } \\
\text { Гoxic- }\end{array}$ & cy; & & $\begin{array}{l}\text { TDD - } \\
\text { SC - S } \\
\text { SC Pts } \\
\text { Exp to }\end{array}$ & $\begin{array}{l}\text { - Gec } \\
\text { tratio } \\
\text { air(m } \\
\text { heore } \\
\text { arce C } \\
\text { Sour } \\
\text { (cat } \\
\text { ant; }\end{array}$ & $\begin{array}{l}\text { 3); } \\
\text { ribu } \\
\text { ribut } \\
\text { cy } 1\end{array}$ & $\begin{array}{l}\text { ean Mc } \\
\mathrm{r}(\mathrm{mg} / \mathrm{l}) \\
\text { Dose } \\
\mathrm{n} \text {; } \\
\text { Expos }\end{array}$ & jints & $\begin{array}{l}\text { once } \\
\text { (kg), }\end{array}$ & & \multicolumn{7}{|c|}{$\begin{array}{l}\text { Exp to M (cat. 2) - Exposure to Media; } \\
\text { PExp to M (cat.3) - Potential Exposure to } \\
\text { Media; } \\
\text { Exp Used - Exposure Category used to deter- } \\
\text { mine Exposure Points; Exp Pts - Ex- } \\
\text { posure Points. }\end{array}$} \\
\hline
\end{tabular}

Source: http://www.atsdr.cdc.gov/spl/resources/ATSDR_2013_SPL_Detailed_Data_Table.pdf 


\section{REACH Regulation}

REACH (ang. Registration, Evaluation and Authorisation of Chemicals) is a regulation of the European Parliament and Council Regulation (EC) No 1907/2006 concerning the safe use of chemicals through their registration and evaluation, and in some cases, licensing and trade restrictions and the use of certain chemicals. The REACH regulation, applied directly, without the need to be introduced into Polish law. The law entered into force on 1 June 2007 and replaces or amends several of existing Community legislation, both the regulations and directives introduced into Polish law by Law on 11 January 2001 on chemical substances and preparations. REACH applies throughout the European Union, Norway, Iceland and Liechtenstein. Supervision over the implementation of the Regulation deals with the European Chemicals Agency (ECHA) in Helsinki. The main purpose of the REACH regulation is to ensure a high level of health and the environment, implementation of alternative methods for assessing hazards of substances and the free circulation of substances on the internal market. The rules of REACH apply at every stage - from production through to marketing, distribution up to the application on its own form or in a mixture or in the article (based on Regulation (EC) No 1907/2006 of the European Parliament and of the Council, Official Journal of the European Union, L 136/3 and UK REACH Competent Authority Information Leaflet Number 8 - Exemptions - January 2009).

The fundamental aim of the REACH Regulation is to provide a high level of protection of human health and the environment from risks posed by chemicals produced, imported and used or marketed in the European Community. The effective management of risks associated with the use of chemical substances in the workplace gives this possibility.

The regulations encourage the substitution of highly dangerous substances with less hazardous and dangerous technology; less dangerous, if suitable alternatives are available and applicable to an economical and technical point of view.

The purpose of the REACH Regulation is to ensure the free movement of chemical products in an internal market, by introducing a level of chemical requirements for all EU members and to improve the competitiveness and innovation (based on Regulation (EC) No 1907/2006 of the European Parliament and of the Council, Official Journal of the European Union, L 136/3 and UK REACH Competent Authority Information Leaflet Number 8 - Exemptions - January 2009).

\section{Transport of dangerous materials}

For the transport of hazardous materials motor vehicles or vehicle combinations can be used, except a motorcycle or combination of vehicles consisting of a motorcycle and trailer. A combination of vehicles may have only one semi-trailer or trailer. According to ADR, all motor vehicles with a maximum mass over 12 tonnes and first registered as of 1/1/1998 should have a speed limiter set, that it cannot exceed a speed of $90 \mathrm{~km} / \mathrm{h}$ (BubBico R., Di CAVE, S., MazzarotTA, B. 2004, ElShafey M.M. et al. 2009, FÖRSTER H., GÜNTHER W. 2009, GERBEC M. 2008, KunCYTÉ R. et al. 2003).

In Poland, according to the highway code, each truck with a maximum mass exceeding 3.5 tonnes and a vehicle, for which the specified minimum total weight of the vehicle over 3.5 tonnes, must be fitted with approved speed limiter installed by the producer or authorized entity. The speed controller limits the maximum speed of the truck to $90 \mathrm{~km} / \mathrm{h}$. Motor vehicles and trailers intended for use as transport units for transporting dangerous goods must have braking systems with a construction and performance that satisfies the relevant requirements of ECE Regulation No. 13.

Any vehicle for transporting materials and dangerous goods should be provided (according to ADR) in the appropriate safety equipment and fire extinguishers. Some of this equipment is fixed and unchanging regardless of the cargo - a basic piece of equipment, and part is dependent on the physicochemical properties of carriage materials.

Each vehicle carrying dangerous materials and goods should have at least one chock to be placed under the wheels, two standing warning signs, marking the point of failure (e.g., reflective pins, reflective triangles, or flash with an orange light, powered independently from the vehicle's electrical system), warn- 
ing vest or warning clothing for each crew member, a flashlight (which contains no metal surfaces against the sparking) for each crew member.

\section{Summary and conclusions}

As an additional safety equipment, depending on the nature of the cargo includes equipment for respiratory protection (such as an emergency escape mask or respirator with absorber). If the ADR contract is listed special rule S7, a vehicle must also be equipped with personal protective equipment (e.g. apparatus with water for rinsing eyes, glasses, gloves and footwear) and equipment which is necessary to take the additional or special set written in instructions (usually equipment designed for use in the case of small leakages, these are the containers for the collection of bulk materials, a device for inlets sealing, sewers and manholes, sealing putty).

The vehicle has to contain the following documents during transportation of hazardous materials: transport documents, written instructions for the driver, driver's training certificate (if required), certificate of qualification of driver, vehicle-approval certificate for the carriage of certain dangerous goods (for EX/II, EX/III, FL, OX, AT), permission for carriage of certain goods.

The accident instructions for the driver are prepared for every considered material. These instructions include the physicochemical properties of the material and the treatment in the event of an accident. These instructions should include: name of material or product groups, class and UN number, description of cargo, description of cargo. The description should by short, limited to the physical state of the material, e.g., color and smell - to help identify the release of the material, type of threat to the materials (the dominant threat, the threat of additional behavior of the material under the effect of flame or heat, information, whether the transported materials react dangerously with water). A brief description of the remedies that should apply to the driver, personal protective equipment that the driver should have.

\section{References}

1. Bubbico R.; Di Cave, S.; Mazzarotta, B., Risk analysis for road and rail transport of hazardous materials: a GIS approach, J. Loss Prev. Proc. Ind. 2004 pp. 483.

2. Elshafey M.M., ABD El Halim A.O., Isgor O.B., Contestabile E., Katsabanis T., Numerical and experimental investigations for safer transportation of dangerous goods Journal of Transportation Security Volume: 2, Issue: 1-2, June 2009, pp. 13.

3. FÖRSTER H., GÜNTHER W., Explosion protection for vehicles intended for the transport of flammable gases and liquids-An investigation into technical and operational basics Journal of Hazardous Materials Volume: 164, Issue: 2-3, May 30, 2009, pp. 1064.

4. GERBEC M., On the process and implications of drawing up and running a security plan according to ADR in an SME-type company, Journal of Loss Prevention in the Process Industries, Volume: 21, Issue: 6, November, 2008, pp. 604.

5. Kuncyté R., Laberge-Nadeau C., Crainic T.G., READ J.A., Organisation of truck-driver training for the transportation of dangerous goods in Europe and North America Accident Analysis and Prevention Volume: 35, Issue: 2, March, 2003, pp. 191.

6. LeE. C.C., Huffman G.L., OBeracker D.A.: An Overview of Hazardous/Toxic Waste, 1986.

7. OPPELT E.T.: Incineration of Hazadrous Waste, 1987.

8. Oświadczenie Rządowe w sprawie ogłoszenia jednolitego tekstu Umowy europejskiej dotyczącej międzynarodowego przewozu drogowego towarów niebezpiecznych (ADR 2009) Dz. U. Nr 27 poz. 162 z 2009.

9. Regulation (EC) No 1907/2006 of the European Parliament and of the Council, Official Journal of the European Union, L 136/3.

10. Rozporządzenie Ministra Transportu z dnia 1 czerwca 2006 r. zmieniającemu rozporządzenie w sprawie towarów niebezpiecznych, których przewóz drogowy podlega obowiązkowi zgłoszenia (Dz. U. Nr 100, poz. 695).

11. Rozporządzenie Ministra Zdrowia z dnia 3 lipca 2002 r. w sprawie wykazu substancji niebezpiecznych wraz $\mathrm{z}$ ich klasyfikacją i oznakowaniem (Dz. U. Nr 129, poz. 1110).

12. UK REACH Competent Authority Information Leaflet Number 8 - Exemptions - January 2009.

13. Ustawa z dnia 11 stycznia 2001 r. o substancjach i preparatach chemicznych (Dz. U. Nr 11, poz. 84). 